\title{
The Pseudomonas aeruginosa ton $B$ gene encodes a novel TonB protein
}

\author{
Keith Poole, Qixun Zhao, Shádi Neshat, David E. Heinrichs \\ and Charles R. Dean \\ Author for correspondence: Keith Poole. Tel: +1613545 6677. Fax: +1 6135456796 \\ e-mail: poolek@qucdn.queensu.ca
}

Department of Microbiology and Immunology, Queen's University, Kingston, Ontario, K7L 3N6 Canada

\begin{abstract}
The Pseudomonas aeruginosa tonB gene was cloned by complementation of the tonB mutation of Pseudomonas putida strain TE516 (W. Bitter, J. Tommassen \& P. J. Weisbeek, 1993, Mol Microbiol 7, 117-130). The gene was 1025 bp in length, capable of encoding a protein of $36860 \mathrm{Da}$. As with previously described Ton B proteins, the $P$. aeruginosa TonB (TonB $\mathrm{P}_{\mathrm{p} . \mathrm{a}}$ ) was rich in Pro residues $(18.1 \%)$ and contained Glu-Pro/Lys-Pro repeats. Unlike

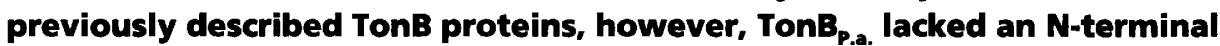
membrane anchor (signal) sequence and contained, instead, a predicted internal signal/anchor sequence, expected to yield an atypical $\mathbf{N}$-terminal cytoplasmic domain in this protein. TonB proteins are essential components in iron-siderophore uptake in bacteria, apparently functioning as energy transducers in coupling the energized state of the cytoplasmic membrane to outer-membrane receptor function. As expected, ton $B$ derivatives of $P$. aeruginosa were defective in siderophore-mediated iron acquisition. ton $B$ gene expression was inducible by iron-limitation, consistent with the identification of a Fur consensus binding sequence upstream of the gene. TonB $_{\text {p.a. }}$ showed substantially greater similarity to the Escherichia coli TonB protein than the Pseudomonas putida protein (31\% identity vs. $20 \%$ identity) and ton $B_{\text {p.a. }}$ was able to complement deficiencies in the acquisition of ferric enterobactin and vitamin $B_{12}$, and sensitivity to phage $\phi 80$ of an $E$. coli ton $B$ strain. The larger size of Ton $B_{p . a .}$ and its ability to function in both $E$. coli and $P$. putida make it a unique TonB protein whose characterization should enhance our understanding of TonB function in bacteria.
\end{abstract}

Keywords: Pseudomonas aeruginosa, iron transport, siderophore, tonB

\section{INTRODUCTION}

Energy-dependent receptor-mediated ligand uptake across the outer membrane of Gram-negative bacteria is dependent upon the function of the product of the ton $B$ gene (Postle, 1990a, 1993). This Pro-rich protein is, in Escherichia coli, anchored to the cytoplasmic membrane via its $\mathrm{N}$ terminus and extends into the periplasm (Postle \& Skare, 1988; Roof et al., 1991; Hannavy et al., 1990) where it appears to interact with receptor proteins in the outer membrane (Heller et al., 1988; Günter \& Braun, 1990;

Abbreviations: BHI, Brain Heart Infusion; EDDHA, ethylenediamine di(o-hydroxyphenylacetic acid); Ton $B_{E . c .}$ TonB of Escherichia coli; ton $B_{\text {P.a. }} / T_{0} B_{\text {P.a. }}$ tonB $B$ Ton B of Pseudomonas aeruginosa.

The GenBank accession number for the $\operatorname{ton} B_{\text {p.a. }}$ nucleotide sequence reported in this paper is U23764.
Bell et al., 1990; Skare et al., 1993; Schöffler \& Braun, 1989). This disposition of the protein reflects its apparent role in coupling the energized state of the cytoplasmic membrane to the outer-membrane receptors (Postle, 1990a, 1993). Current models of TonB-dependent receptors describe them as gated porins whose activities are modulated by the action of the TonB protein (Rutz et al., 1992; Killmann et al., 1993). These receptors, which include receptors for ferric siderophores (Braun et al., 1987), vitamin $B_{12}$ (Heller \& Kadner, 1985), haem/ haemin (Jarosik et al., 1994; Stojiljkovic \& Hantke, 1992; Henderson \& Payne, 1994) and transferrin (Jarosik et al., 1995; Cornelisson et al., 1992), show conserved regions of homology (Lundrigan \& Kadner, 1986), one of which, the so-called TonB box (Schrammet al., 1987), is proposed to interact directly with TonB (Heller et al., 1988; Bell et al., 1990). Such interaction appears to be mediated by a region of the TonB protein at or near residue Glu- 160 
(Heller et al., 1988; Bell et al., 1990) or by the C terminus (Larsen et al., 1993) which is required for TonB activity (Anton \& Heller, 1991; Bruske \& Heller, 1993). The Prorich domain of TonB, which is responsible for the anomalous migration of the protein on SDSpolyacrylamide gels (Larsen et al., 1993), is predicted to adopt an elongated, structurally constrained conformation (Evans et al., 1986; Brewer et al., 1990) consistent with an apparent role in extending downstream/Cterminal TonB sequences actoss the periplasmic space where they can interact with receptor molecules (Larsen $e t$ al., 1993).

Full TonB function in E. coli is dependent upon the products of the $e x b B$ and $e x b D$ genes (Guterman \& Dann, 1973; Hantke \& Zimmermann, 1981; Eick-Helmerich \& Braun, 1989) found in the cytoplasmic membrane (Kampfenkel \& Braun, 1992; Kampfenkel \& Braun, 1993). The former is involved both in the stabilization of TonB (Karlsson et al., 1993b; Skare \& Postle, 1991; Fischer et al., 1989), apparently via an interaction with the TonB N terminus (Larsen et al., 1994; Karlsson et al., 1993a; Jaskula et al., 1994; Traub et al., 1993), and in the energy transduction process itself (Skare et al., 1993). Both tonB (Postle \& Good, 1983; Bruske \& Heller, 1993) and the exb (Eick-Helmerich \& Braun, 1989) genes are preceded by Fur consensus binding sequences, consistent with the observed increase in expression of these genes under conditions of iron-limitation (Postle, 1990b; Hantke \& Zimmermann, 1981).

ton $B$ genes have been identified and characterized in a number of bacteria including Salmonella typhimurium (Hannavy et al., 1990), Serratia marcescens (Gaisser \& Braun, 1991), Enterobacter aerogenes (Bruske \& Heller, 1993), Klebsiella pneumoniae (Bruske et al., 1993), Yersinia enterocolitica (Koebnik et al., 1993), Pseudomonas putida (Bitter et al., 1993), Haemophilus infuenzae (Jarosik et al., 1994) and Haemophilus ducreyi (Klesney-Tait et al., 1994). With the exception of the proteins from Haemopbilus spp. (30-31\% identity) and $P$. putida ( $28 \%$ identity), the TonB proteins exhibit a very high degree of sequence similarity (56-95\% identity) with the E. coli TonB protein $\left(\mathrm{TonB}_{\mathrm{E.c.}}\right)$. While the ton $B$ gene is not linked to $e x b B$ and exbD homologues in most of the bacteria where they have been identified, the three genes appear to form an operon in P. putida and H. influenzae (Bitter et al., 1993; Jarosik et al., 1994).

$P$. aeruginosa expresses a number of outer-membrane proteins with homology to TonB-dependent receptors, including receptors for the ferric complexes of the siderophores pyoverdine (Poole et al., 1993c), pyochelin (Heinrichs et al., 1991; Ankenbauer \& Quan, 1994) and enterobactin (Dean \& Poole, 1993a). This homology and the fact that the $P$. aeruginosa ferric enterobactin receptor PfeA is active in E. coli (Dean \& Poole, 1993a) suggests that receptor-mediated ferric siderophore uptake in $P$. aeruginosa utilizes a TonB-like system and, therefore, that a ton $B$ homologue exists in this organism. In this report we identify and characterize a $P$. aeruginosa ton $B$ gene $\left(\operatorname{ton} B_{P . a}\right)$ which can functionally replace the $\operatorname{ton} B$ genes of E. coli and $P$. putida.

\section{METHODS}

Bacterial strains and plasmids. Bacterial strains and plasmids used in this study are described in Table 1. Spontaneous streptomycin-resistant derivatives of $P$. aeruginosa were isolated by harvesting $5 \mathrm{ml}$ of an overnight L-broth culture and plating the pellet (resuspended in $100 \mu \mathrm{l}$ ) on L-agar containing $1000 \mu \mathrm{g}$ streptomycin $\mathrm{ml}^{-1}$. Distinct colonies appearing after 24-48 h incubation at $37^{\circ} \mathrm{C}$ were recovered. For the construction of pTON-6, a ca $1.4 \mathrm{~kb} \mathrm{BamHI}$ fragment of pTON-4 carrying the $5^{\prime}$ end of ton $B$ and upstream sequences was cloned into the unique $B g / I I$ site of pMP190 such that $\operatorname{ton} B$ was in the same orientation as the downstream, promoterless $\operatorname{lac} Z$ gene of this vector (Fig. 1). In constructing pTON-11, a ca $1.2 \mathrm{~kb}$ MscI-BsrBI fragment of pTON-4, also carrying the $5^{\prime}$ end of tonB and upstream sequences, was cloned into the unique $S \mathrm{maI}$ site of $\mathrm{pPZ} 30$, such that $\operatorname{ton} B$ was in the same orientation and inframe with the downstream lacZ gene of this vector (Fig. 1).

Growth conditions. The iron-deficient minimal medium used has been described previously (Poole et al., 1991). Succinate was replaced with glucose $(0.4 \%, \mathrm{w} / \mathrm{v})$ in this medium when culturing $E$. coli cells. Arginine- $\mathrm{HCl}(1 \mathrm{mM})$ and methionine $(1 \mathrm{mM})$ were included in minimal medium as needed. L-broth (Poole et al., 1990) or, where indicated, Brain Heart Infusion (BHI, Difco) were employed as the rich media. Antibiotics, including ampicillin $\left(100 \mu \mathrm{g} \mathrm{ml}^{-1}\right)$, streptomycin $\left(500 \mu \mathrm{g} \mathrm{ml}^{-\mathbf{1}}\right.$, or as indicated) chloramphenicol $\left(30 \mu \mathrm{g} \mathrm{ml}^{-1}, \mathrm{E}\right.$. coli; $200 \mu \mathrm{g} \mathrm{ml}^{-1}, P$. aeruginosa), tetracycline $\left[10 \mu \mathrm{g} \mathrm{ml}^{-1}\right.$, E. coli; $25 \mu \mathrm{g} \mathrm{ml}^{-1}$ (minimal medium) or $40 \mu \mathrm{g} \mathrm{ml}^{-1}$ (rich medium), $P$. putida], nalidixic acid $\left(25 \mu \mathrm{g} \mathrm{ml}^{-1}\right)$ and $\mathrm{HgCl}_{2}\left(15 \mu \mathrm{g} \mathrm{ml}^{-1}\right)$ were included in growth media as appropriate. Solid media were obtained by the addition of Agar-agar (BDH) at $1.5 \%(\mathrm{w} / \mathrm{v})$. Bacteria were cultured at $37^{\circ} \mathrm{C}$ (E. coli and $P$. aeruginosa) or $30^{\circ} \mathrm{C}$ (P. putida).

DNA methods. Plasmid DNA was routinely prepared by the alkaline lysis procedure (Sambrook et al., 1989). For sequencing purposes the DNA was purified on $\mathrm{CsCl}$ gradients (Sambrook et al., 1989) or using the Wizard Minipreps DNA Purification System (Promega) as outlined by the manufacturer. Restriction endonucleases and T4 ligase were obtained from Life Technologies or NEB and used according to the manufacturers' instructions or as described by Sambrook et al. (1989). Transformation of E. coli (Sambrook et al., 1989) and P. aeruginosa (Berry \& Kropinski, 1986) with plasmid DNA were performed as described. Restriction fragments were isolated, as required, from agarose gels $(0.8-1.5 \%, \mathrm{w} / \mathrm{v})$ using the Prep-a-gene system (Bio-Rad) as directed by the manufacturer. Introduction of plasmid (pRK415 and its derivatives) (Fig. 1) or cosmid (pLAFR3 library) (see below) DNA into $P$. putida required a triparental mating procedure employing the helper vector pRK2013 (Figurski \& Helinski, 1979). Briefly, $100 \mu \mathrm{l}$ of overnight cultures of plasmid-/cosmid-containing E. coli $5 \mathrm{~K}$ or HB101, pRK2013-containing E. coli MM294 and P. putida TE156 were pelleted together in a microfuge tube, resuspended in $25 \mu \mathrm{l} \mathrm{L}$-broth and spotted onto the centre of an L-agar plate. Following incubation overnight at $30^{\circ} \mathrm{C}$, bacterial growth was resuspended in $1 \mathrm{ml} \mathrm{L-broth,} \mathrm{plated} \mathrm{on} \mathrm{L-agar} \mathrm{containing}$ tetracycline (to select for plasmid-/cosmid-containing TE156) and nalidixic acid (to select against the $E$. coli strains) and incubated for $1-2 \mathrm{~d}$ at $30^{\circ} \mathrm{C}$.

Construction of a pLAFR3 library of $P$. aeruginosa PAO1 chromosomal DNA. Chromosomal DNA of $P$. aeruginosa PAO1, prepared by the method of Marmur (1961), was subjected to partial Sau3A digestion and fractionated on a sucrose gradient as described (Sambrook et al., 1989). Fractions enriched for DNA of $20 \mathrm{~kb}$ in length (as determined by agarose gel electrophoresis) 
Table 1. Bacterial strains and plasmids

\begin{tabular}{|c|c|c|}
\hline Strain/plasmid & Description/phenotype* & Source/reference \\
\hline \multicolumn{3}{|l|}{ E. coli } \\
\hline $5 \mathrm{~K}$ & thr lac $Z$ rpsL thi ser bsdR bsdM & Poole et al. (1988) \\
\hline MM294 & supE44 $\lambda^{-} r f b D 1$ spo $T$ thi-1 end $A 1$ bsdR 17 pro & Neidhardt (1987) \\
\hline HB101 & $\mathrm{F}^{-}$hsdS $20\left(\mathrm{r}_{\mathrm{B}}^{-} \mathrm{m}_{\mathrm{B}}^{-}\right) \operatorname{rec} A 13$ ara14 proA2 lacY1 galK2 rpsL20 xyl-5 mtl-1 supE44 $\lambda^{-}$ & Neidhardt (1987) \\
\hline RK5173 & $\begin{array}{l}\mathrm{F}^{-} \Delta(\operatorname{argF}-\text { lac }) U 169 \text { araD139 relA1 rpsL150 flb-5301 deoC1 thi gyr A219 non } \\
\text { metE70 }\end{array}$ & Heller et al. (1988) \\
\hline RK5015 & RK5173 $\Delta \operatorname{ton} B$ & Heller et al. (1988) \\
\hline \multicolumn{3}{|l|}{ P. putida } \\
\hline WCS358 & Wild-type thizosphere strain & Bitter et al. (1993) \\
\hline TE156 & WCS358 ton $B:: \operatorname{Tn} 5$ & Bitter et al. (1993) \\
\hline \multicolumn{3}{|l|}{ P. aeruginosa } \\
\hline K199 & PAO1 wild-type & \\
\hline K335 & Spontaneous streptomycin-resistant derivative of K199 & This study \\
\hline PAO6609 & met 9011 amiE200 rpsL pvd9 & Hohnadel et al. (1986) \\
\hline K372 & $\begin{array}{l}\text { Derivative of PAO } 6609 \text { deficient in pyochelin and the ferric pyochelin receptor } \\
\text { FptA; probable } p c b \mathrm{R} \text { mutant }\end{array}$ & $\begin{array}{l}\text { Heinrichs et al. (1991); } \\
\text { Heinrichs \& Poole (1993) }\end{array}$ \\
\hline K883 & PAO6609 tonB:: $\Omega \mathrm{Hg}$ & This study \\
\hline K886 & $\mathrm{K} 372$ tonB:: $\Omega \mathrm{Hg}$ & This study \\
\hline \multicolumn{3}{|l|}{ Plasmids } \\
\hline pLAFR3 & Broad-host-range cosmid cloning vector; $\mathrm{Tc}^{\mathrm{r}}$ & Staskawicz et al. (1987) \\
\hline pRK415 & Broad-host-range cloning vector; $\mathrm{Tc}^{\mathrm{r}}$ & Keen et al. (1988) \\
\hline pRK2013 & Broad-host-range (ColE1 $\operatorname{Tra}_{\mathrm{RP1}}$ ) helper vector; $\mathrm{Km}^{\mathbf{r}}$ & Figurski \& Helinski (1979) \\
\hline $\mathrm{pHP} 45 \Omega \mathrm{Hg}$ & $\begin{array}{l}\text { Derivative of } \mathrm{pHP} 45: \Omega \text { where the } \mathrm{Sm}^{\mathrm{r}} / \mathrm{Sp}^{\mathrm{r}} \text { of the } \Omega \text { interposon is replaced by } \\
\text { the } \mathrm{HgCl}_{2} \text { resistance operon of } \operatorname{Tn} 501\end{array}$ & Fellay et al. (1987) \\
\hline pUCP18/19 & E. coli-P. aeruginosa shuttle cloning vector; $\mathrm{Ap}^{\mathrm{r}} / \mathrm{Cb}^{\mathrm{r}}$ & Schweizer (1991a) \\
\hline pMP190 & $\begin{array}{l}\text { Broad-host-range, low-copy-number lac } Z \text { transcriptional fusion vector; } \mathrm{Cm}^{\mathrm{r}} \\
\mathrm{Sm}^{\mathrm{r}}\end{array}$ & Spaink et al. (1987) \\
\hline pSUP202 & $\begin{array}{l}\text { pBR325 derivative carrying the Mob (mobilization) site of plasmid RP4; gene } \\
\text { replacement vector; } \mathrm{Ap}^{\mathrm{r}} / \mathrm{Cb}^{r}, \mathrm{Tc}^{\mathrm{r}}, \mathrm{Cm}^{\mathrm{r}}\end{array}$ & Simon et al. (1983) \\
\hline pSUP202 $2 \mathrm{Tc}$ & $\begin{array}{l}\text { Derivative of pSUP202 carrying a deletion within the tet gene removing the } \\
\text { unique Bam HI and HindIII sites in this vector; } \mathrm{Ap}^{\mathrm{r}} / \mathrm{Cb}^{r}, \mathrm{Cm}^{\mathrm{r}}\end{array}$ & Dean \& Poole (1993b) \\
\hline $\mathrm{pPZ30}$ & Broad-host-range lac $Z$ translational fusion vector; $\mathrm{Ap}^{\mathrm{r}} / \mathrm{Cb}^{\mathrm{r}}$ & Schweizer (1991b) \\
\hline $\mathrm{pEX} 100 \mathrm{~T}$ & pUC19-based gene replacement vector; $A p^{r}$ & Schweizer \& Hoang (1995) \\
\hline p'TON-12 & pSUP202 $\triangle \mathrm{Tc}:: \operatorname{ton} B:: \Omega \mathrm{Hg}$ & This study \\
\hline pTON-13 & $\mathrm{pEX} 100 \mathrm{~T}:: \operatorname{ton} B:: \Omega \mathrm{Hg}$ & This study \\
\hline
\end{tabular}

*Ap ${ }^{r}$, ampicillin-resistant; $\mathrm{Cb}^{\mathrm{r}}$, carbenicillin-resistant; $\mathrm{Cm}^{\mathrm{r}}$, chloramphenicol-resistant $\mathrm{Sm}^{\mathrm{r}}$, streptomycin-resistant; Sp ${ }^{\mathrm{r}}$, spectinomycinresistant; $\mathrm{Tc}^{\mathrm{r}}$, tetracycline-resistant; ton $\mathrm{B}: \mathrm{\Omega Hg}$, ton $B$ gene distupted by insertion of the $\Omega \mathrm{Hg}$ interposon.

were recovered, dialysed to remove the sucrose and ligated to the broad-host-range cosmid cloning vector pLAFR3 previously treated with $B a m \mathrm{HI}$ and calf intestinal alkaline phosphatase (Sambrook et al., 1989). Following in vitro packaging of the ligated DNA using the Packagene Lambda DNA Packaging System (Promega) and infection of E. coli HB101, cosmidcontaining HB101 clones were recovered on tetracyclinecontaining L-agar. Approximately 2000 individual colonies were obtained and analysis of the cosmids from 18 randomly selected colonies revealed a variety of inserts of $c a 15-25 \mathrm{~kb}$ in each case. The colonies were recovered in batches of 10 , cultured overnight in L-broth containing tetracycline and stored at $-20^{\circ} \mathrm{C}$.

Cloning of the ton $B_{\text {p.a. }}$ gene. The pLAFR3 library of $P$. aeruginosa chromosomal DNA was mobilized en masse into the $P$. putida tonB strain TE156 using pRK2013 and a triparental mating procedure (see above). Following the overnight incubation, however, bacterial growth was resuspended in $1 \mathrm{ml}$ of iron-deficient (succinate) minimal medium and washed three times in the same medium before being plated onto irondeficient (succinate) minimal medium plates containing tetracycline and nalidixic acid. Cosmid DNA was subsequently prepared from colonies appearing after $48 \mathrm{~h}$ incubation at $30^{\circ} \mathrm{C}$ and re-introduced into TE156 via triparental mating to confirm the ability of the cosmid DNA to facilitate growth of TE156 on iron-deficient minimal medium.

Nucleotide sequencing. DNA for sequencing was obtained as double-stranded template and sequenced by the Centres of Excellence Core Facility for Protein/DNA Chemistry at Queen's University. Overlapping sequence from both strands was obtained using a series of custom-synthesized primers. Because of difficulties in cloning the $2.8 \mathrm{~kb}$ tonB-containing Pst $\mathrm{I}$ 


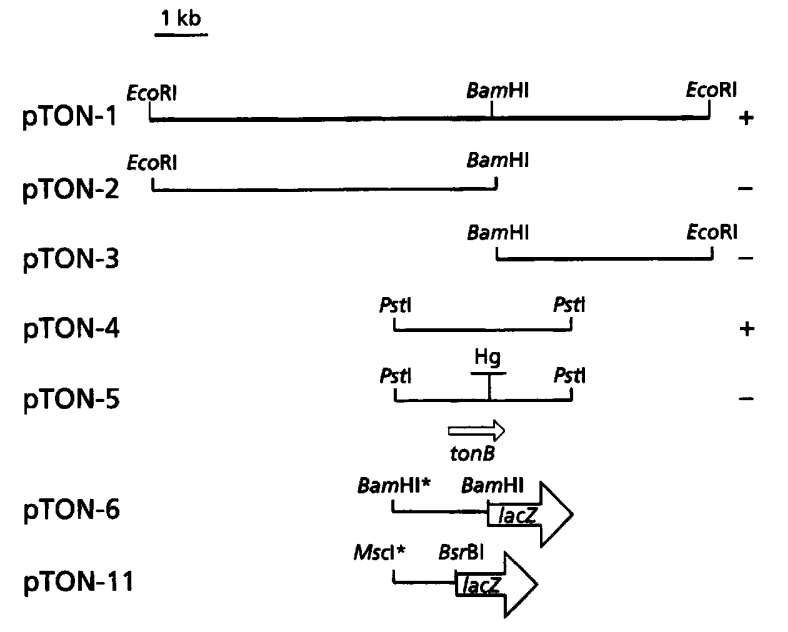

Fig. 1. Subcloning of the $P$. aeruginosa ton $B$ gene and generation of tonB-lacZ transcriptional/translational fusions. The indicated restriction fragments were cloned into vector pRK415 (pTON-1 to -5) and introduced into $P$. putida TE156 where they were assessed for an ability to restore growth on an iron-limited minimal medium ( + , growth; - , no growth). The BamHI site of insertion of an $\Omega \mathrm{Hg}$ interposon is indicated, as is the position and orientation of the ton $B_{\text {p.a. }}$ gene. The $5^{\prime}$ region of $\operatorname{ton} B_{\text {P.a. }}$ and upstream sequences were isolated on a $B a m H I$ fragment or a Mscl-BsrBI fragment from pTON-4 and cloned, respectively, into the lacZ transcriptional fusion vector pMP190 (to generate $\mathrm{pTON}-6$ ) and the lacZ translational fusion vector pPZ30 (to generate pTON-11). BamHI* indicates a BamHI site in the pRK415 multicloning site. Mscl* indicates a non-unique Mscl site from pTON-4.

fragment of p'TON-4 onto sequencing vectors such as pUCP18/19, this region was actually cloned as two separate BamHI-Pst I fragments in pUCP18 and sequenced. A $500 \mathrm{bp}$ $M s c \mathrm{I}$ fragment which encompasses the $B a m \mathrm{HI}$ site in $\operatorname{ton} B$ was also cloned in pUCP18 and sequenced to provide sequence data across this restriction site. Nucleotide and deduced amino acid sequences were analysed using the PC Gene software package (Intelligenetics).

Expression of the cloned ton $B_{\text {p.a. }}$ gene. To identify the product of the cloned $\operatorname{ton} B_{\text {P.a. }}$ gene, the phage T7-based expression system of Tabor \& Richardson (1985) was employed as described previously (Poole et al., 1993a).

In vitro mutagenesis of $\operatorname{ton} B_{\text {p.a. }}$. The cloned $\operatorname{ton} B_{\text {P.a. }}$ gene was mutagenized in vitro by the insertion of an $\mathrm{HgCl}_{2}$ resistance interposon $(\Omega \mathrm{Hg})$ into the unique Bam HI site in tonB $B_{\text {P.a. }}$. Briefly, the $\operatorname{ton} B_{\mathrm{P} . \mathrm{a} \text { - }}$-containing $2.8 \mathrm{~kb}$ Pst $\mathrm{I}$ fragment of plasmid p'TON4 was cloned into pSUP $202 \Delta \mathrm{Tc}$, a derivative of the gene replacement vector pSUP202 carrying a deletion in the tet gene which eliminates the previously unique Bam $\mathrm{HI}$ and HindIII sites in this vector. This recombinant (pTON-12) was subsequently digested with $B a m H I$ and ligated to a $5 \mathrm{~kb} \mathrm{BamHI}$ fragment of plasmid pHP45 $\Omega \mathrm{Hg}$ carrying the $\Omega \mathrm{Hg}$ interposon. The tonB: $: \Omega \mathrm{Hg}$ construct was then recovered on a $7.8 \mathrm{~kb}$ Pst $\mathrm{I}$ fragment and cloned into the unique Pst I site of pRK415 to yield pTON-5 (Fig. 1).

Construction of a P. aeruginosa tonB mutant. Introduction of pTON-12 into E. coli $\mathrm{S} 17-1$ and mobilization into $P$. aeruginosa via conjugation, according to a previously described procedure
(Poole et al., 1993a), failed to generate the desired tonB:: $\Omega \mathrm{Hg}$ strains of $P$. aeruginosa. Thus, the ton $B:: \Omega \mathrm{Hg}$-carrying $7.8 \mathrm{~kb}$ Pst I fragment (see above) was cloned into the unique $S m a \mathrm{I}$ site of the gene replacement vector $\mathrm{pEX} 100 \mathrm{~T}$ following conversion of this site to a Pst I site with Pst I linkers (Stratagene) according to the manufacturer's instructions. The recombinant $\mathrm{pEX100T}$ carrying the $\Omega \mathrm{Hg}$-disrupted ton $B$ gene (called pTON-13) was subsequently transformed into $E$. coli S17-1 and mobilized into $P$. aeruginosa via conjugation as described by Poole $e t$ al. (1993a). To permit counterselection of the donor $E$. coli strain in these experiments, the recipient $P$. aeruginosa strains were either streptomycin-resistant or spontaneous streptomycin-resistant derivatives were isolated as described above. Following conjugation, the mating mixture was plated on L-agar containing streptomycin, $\mathrm{HgCl}_{2}$ and sucrose $(5 \%, \mathrm{w} / \mathrm{v})$ and colonies appearing after $48-72 \mathrm{~h}$ incubation at $37^{\circ} \mathrm{C}$ were recovered. The $\operatorname{ton} B$ genes were amplified (by PCR) from representative colonies of each mating to confirm disruption of the chromosomal tonB gene by replacement with the tonB:: $\Omega \mathrm{Hg}$ construct. Briefly, chromosomal DNA was prepared as described by Ausubel et al. (1992) from $P$. aeruginosa tonB: $: \Omega \mathrm{Hg}$ candidates and amplified using Taq DNA polymerase (Life Technologies) and primers tonB1 ( 5 ' CCTGCCATGCGTGAATGC 3') beginning at position 203 of the sequence presented in Fig. 1 and tonB2 (5' AGAACATCTTGGTCGCCTGG 3') complementary to and beginning at position 1108 of the Fig. 1 sequence. The reaction mixture $(100 \mu \mathrm{l})$ contained $2.5 \mathrm{U}$ Taq DNA polymerase, $0.5 \mu \mathrm{M}$ each primer, $0.2 \mathrm{mM}$ each deoxynucleoside triphosphate, $1.5 \mathrm{mM} \mathrm{MgCl}, 10 \%$ (v/v) dimethylsulphoxide, $100 \mathrm{ng}$ genomic DNA and $1 \times$ PCR buffer (Life Technologies). The mixture was treated for $2 \mathrm{~min}$ at $94^{\circ} \mathrm{C}$ followed by 35 cycles of $45 \mathrm{~s}$ at $94^{\circ} \mathrm{C}, 1 \mathrm{~min}$ at $52^{\circ} \mathrm{C}$ and $2 \mathrm{~min}$ at $72^{\circ} \mathrm{C}$, before finishing with $10 \mathrm{~min}$ at $72^{\circ} \mathrm{C}$. PCR products were examined on $0.8 \%(\mathrm{w} / \mathrm{v})$ agarose gels.

Growth assays of $P$. aeruginosa ton $B$ mutants. ton $B$ mutants and their parent strains were cultured at $37^{\circ} \mathrm{C}$ overnight in $\mathrm{BHI}$ broth and subsequently diluted into BHI broth in the presence and absence of ethylenediamine di(o-hydroxyphenylacetic acid) (EDDHA) $\left(25 \mu \mathrm{g} \mathrm{ml}^{-1}\right.$ for PAO6609 and its ton $B$ derivative $\mathrm{K} 883 ; 10 \mu \mathrm{g} \mathrm{ml}^{-1}$ for $\mathrm{K} 372$ and its tonB derivative K886) to a final $\mathrm{OD}_{600}$ of $0 \cdot 05-0 \cdot 1$. Bacterial growth was assayed by monitoring the change in $\mathrm{OD}_{600}$ over time of cultures shaken (200 r.p.m.) at $37^{\circ} \mathrm{C}$. To assess the ability of ton $B$ mutants and their parents to utilize siderophores, $1 \mathrm{ml}$ irondeficient (succinate) minimal medium containing EDDHA $\left(150 \mu \mathrm{g} \mathrm{ml}^{-1}\right)$, with and without siderophore supplementation [pyoverdine, $100 \mu \mathrm{g} \mathrm{ml}^{-1}$; enterobactin, $50 \mu$ l concentrated $E$. coli culture supernatant $\mathrm{ml}^{-1}$ (see below)], was inoculated with $10^{7}$ organisms, incubated overnight at $37^{\circ} \mathrm{C}$ and assessed visually for growth.

Growth promotion by pyoverdine and pseudobactin. The $P$. putida WCS358 tonB strain TE156 (10 7 organisms) was plated onto the surface of an iron-deficient (succinate) minimal plate and filter discs impregnated with various concentrations of pyoverdine $_{\mathrm{PAO}_{\mathrm{O}}}$ (prepared from $P$. aeruginosa $\mathrm{PAO} 1$ ) and pseudobactin $_{358}$ (prepared from $P$. putida WCS358) placed on the plates. Following overnight incubation at $30^{\circ} \mathrm{C}$, plates were examined for evidence of growth in the region surrounding the filter discs.

Growth promotion by enterobactin. Enterobactin-containing 25-fold concentrated spent culture supernatant was prepared from 1 litre overnight cultures of E. coli JR20 as described previously (Poole et al., 1990). To assess the ability of this enterobactin to stimulate the growth of selected $E$. coli strains and their plasmid-containing derivatives, strains were cultured 
Pseudomonas aeruginosa ton $B$ gene

overnight in iron-deficient (glucose) minimal medium supplemented with arginine and methionine and diluted to an $\mathrm{OD}_{600}$ of 0.05 in the same medium containing EDDHA $\left(100 \mu \mathrm{g} \mathrm{ml}^{-1}\right)$ and enterobactin $(7.5 \mu \mathrm{l}$ concentrated spent culture supernatant $\left.\mathrm{ml}^{-1}\right)$. Cultures were incubated at $37^{\circ} \mathrm{C}$ with shaking and growth (change in $\mathrm{OD}_{600}$ ) monitored over time. Plate assays of enterobactin growth promotion were carried out by plating $10^{7}$ organisms onto iron-deficient (glucose) minimal medium plates containing arginine, methionine and EDDHA (see above) and overlaying filter discs impregnated with varying concentrations of enterobactin (as concentrated culture supernatant). Following overnight incubation at $37^{\circ} \mathrm{C}$, plates were examined for evidence of growth surrounding the filter discs.

Growth promotion by vitamin $\mathbf{B}_{\mathbf{1 2}}$. To assess the ability of vitamin $\mathrm{B}_{12}$ to promote the growth of selected $E$. coli met $E$ strains and their plasmid-containing derivatives, these strains were cultured overnight in iron-deficient minimal (glucose) medium supplemented with vitamin $\mathrm{B}_{12}(5 \mathrm{nM})$ and diluted to $\mathrm{OD}_{600}=0.05$ in the same medium. Cultures were then incubated at $37^{\circ} \mathrm{C}$ with shaking and growth monitored as described above. Plate assays of vitamin $B_{12}$ growth promotion were carried out as described above except that the plates were not supplemented and the discs were impregnated with varying concentrations of vitamin $\mathrm{B}_{12}$.

Plate assay for phage sensitivity. To assess the sensitivity of various E. coli strains to phage $\phi 80,5 \mu 110$-fold dilutions of a phage stock were spotted onto L-agar plates streaked with $10^{7}$ bacteria. Plaque formation was assessed following overnight incubation at $37^{\circ} \mathrm{C}$.

$\beta$-Galactosidase assays. $P$. aeruginosa carrying derivatives of the lac $Z$ fusion vector pMP190 were cultured overnight at $37^{\circ} \mathrm{C}$ in BHI containing chloramphenicol and diluted 100 -fold into fresh $\mathrm{BHI}$ without antibiotic. Following growth to early exponential phase, EDDHA was added, where indicated, and all cultures incubated a further $1.5 \mathrm{~h}$ before being assayed for $\beta$-galactosidase activity as described by Miller (1992).

\section{RESULTS}

\section{Cloning of ton $B_{\text {p.a. }}$}

To clone $\operatorname{ton} B_{P . a .}$, attempts were made to complement the growth defect of a $P$. putida tonB strain (TE156) on irondeficient minimal medium. Thus, a pLAFR3 library of $P$. aeruginosa $\mathrm{PAO}$ DNA was moved into $P$. putida TE156 and colonies growing on iron-deficient minimal medium recovered. Cosmid DNA isolated from these colonies exhibited a common $8.5 \mathrm{~kb}$ EcoRI fragment which itself was able to restore growth of TE156 on iron-deficient minimal medium (Fig. 1; plasmid pTON-1). The fragment also restored the ability of TE156 to utilize iron-siderophore complexes as confirmed by pyoverdineand pseudobactin-dependent growth of pTON-1-containing TE156 (but not TE156 itself) on EDDHAcontaining minimal medium (data not shown). Cleavage at the unique Bam HI site on the EcoRI fragment (plasmids pTON-2 and PTON-3) abolished complementation of the growth defect (Fig. 1), suggesting that this restriction site occurs within the complementing gene. Indeed, a $2.8 \mathrm{~kb}$ Pst $\mathrm{I}$ fragment encompassing the BamHI site (pTON-4) restored growth of TE156 on iron-deficient medium and insertion of $\Omega \mathrm{Hg}$ into the BamHI site (pTON-5) abolished growth restoration (Fig. 1).

\begin{abstract}
$-35$ $-10$

GGTCGCGGATGATCCGCCAAGGTTGCCCTGAGGACGCGACTGAATGATAATAALIATCA 60

S.D. tonB>

GAAGACTCTACTICCTTACCTTTCACTTCTCCGCAGGTCGCCCTCATGTCGCCACAGCCT 120 $M$ S $P \underset{B S T B I}{O}$

TCACGGTCGCCTGACCGTITTTCGCTGGCCGCGCTCGCCGAAGACCACCCCACCGCTCCC 180

$S$ S $S$ S $P$ P

GCCCAGGgagaCGAAAGCGAGTCCCTGCCATGCGTGAATGCCCAGCGGGGaGAGCCCAAC 240 $A$ O G D E S E S L P C V N A O R G E P N

CTGCGCGTGGTGGACTGCTCCGGTGCGCGCCGCGACGAGGAAGTGGCGGICGAGGAAGTG 300 $L R$ V V D C S G A R R D E E V A V E E V

CTGATCCCCTACGCCCACGgCAGCGATCCCGAAGACGTCCCCGGCGAGCCGCCCAAGTCG 360 $L$ I $P$ Y $A$ A H G S D P E D V P G E P P $K$ K S

CGCTGGTGGTTGTCCTCCGGCGCAGCGGTGGCGATGCATGTGGCGATCATCGGTGCGCTG 420

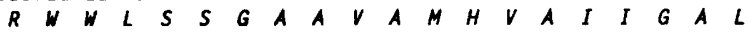

GTGTGGGTGATGCCGACCCCGGCCGAACTCAACCTIGGCCACGGGGAACTGCCGAAGACC 480

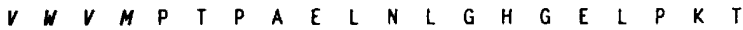

ATGCAGGTGAATITCGTCCAGCTCGAGAAGAAGGCCGAGCCGACCCCGCAGCCGCCGGCT 540

M Q V N N F V Q L E K K A E

GCCGCGCCGgAaCCGACGCCGCCGAaGATCGAGGAACCCAAGCCGGAGCCGCCGAAGCCG 600

A A

AAGCCGGTGGAAAAACCCAAGCCCAAGCCGAAACCCAAGCCCAAACCGGTGGAAAACGCC 660 $K$ K P V E K $F$

AITCCCAAGgCCAAGCCGAaGCCGGAACCCAAACCCAAGCCGGAACCCGAGCCGAGCACG 720

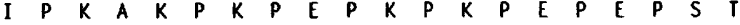

GAAGCATCCAGCCAGCCCAGCCCGTCCAGCGCCGCGCCGCCGCCCGCGCCTACCGTCGGG 780 $E$ A S S O P S P S S A A P P P A P T V G

CAGAGCACGCCCGGCGCGCAGACTGCGCCCAGCGGCTCGCAAGGCCCGGCCGGCCTGCCC 840

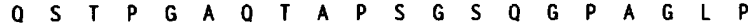
BamHI

AGCGGCAGCCTCAACGACAGCGACATCAAGCCGCTGCGCATGGATCCTCCGGTCTATCCG 900 $S G G S L N$ D S D I K

CGGATGGCCCAGGCGCGGCGTATCGAAGGCCGGGTGAAGGTGCTGTTCACCATCACCAGC 960 $R$ M A O A R R I E G R V K V V L F

GATGgCCGCATtGACGACATCCAGgTGCTGGaGTCGGTGCCGTCGCGCATGITCGACCGC 1020 D G $\quad R$ I

GAAGTGCGCCAGGCCATGGCCAAGTGGCGITICGAGCCGCGTGICAGCGGTGGCAAGATC 1080 E V R O A M A K W R F E P R V S G G K I

GTCGCCCGCCAGGCGACCAAGATGTTCTTCTTCAAGATCGAGAAGCGCCGCTGAGGCGGT 1140 $\checkmark$ A $R$ O
\end{abstract}

ICGCCGACAACGAAAAGAGCCGCGCCIICGAGCGCGGITTITITATTCCCGGTAGGTCTC 1200

Fig. 2. Nucleotide sequence and translation of the $\operatorname{ton} B_{3}$ gene. Putative promoter $(-35,-10)$ and Shine-Dalgarno (S.D.) sequences are indicated, as is a sequence exhibiting homology to the consensus Fur binding sequence (underlined). The BamHI site of insertion of an $\Omega \mathrm{Hg}$ interposon in plasmid pTON-5 (Fig. 1) and the BsrBI site of in-frame fusion to lacZ in plasmid pTON11 (Fig. 1) are also indicated. An internal signal-like sequence in the translated TonB product is italicized.

\section{Nucleotide sequence of ton $B_{\text {P.a. }}$}

To identify the gene(s) complementing the growth defect in the P. putida tonB strain TE156, the region of pTON-4 flanking the Bam $\mathrm{HI}$ site was sequenced. The largest ORF identified (1025 bp) begins with an ATG start codon and was designated ton $B_{\text {P.a. }}$ (Fig. 2). Capable of encoding a polypeptide of 341 amino acids (minus the initiation methionine) with a molecular mass of $36860 \mathrm{Da}$, $\operatorname{ton} B_{\text {P.a. }}$ directed the expression [on plasmid pT7-6 (Tabor \& Richardson, 1985) in E. coli] of a protein of $51 \mathrm{kDa}$ (data 
Table 2. Iron-regulated $\beta$-galactosidase activity of $P$. aeruginosa carrying ton $B-l a c Z$ transcriptional and translational fusions

$P$. aeruginosa $\mathrm{PAO} 6609$ carrying a ton $B-l a c Z$ transcriptional (pTON-6) or translational (pTON-11) fusion was cultured overnight in $\mathrm{BHI}$ broth containing the appropriate antibiotic and subcultured into the same medium supplemented with the indicated concentrations of EDDHA. Following growth to exponential phase, the cultures were assayed for $\beta$-galactosidase activity as described in Methods.

\begin{tabular}{|c|c|c|}
\hline Vector & EDDHA ( $\left.\mu \mathrm{g} \mathrm{ml}^{-1}\right)$ & $\begin{array}{c}\beta \text {-Galactosidase activity } \\
\text { (Miller units)* }\end{array}$ \\
\hline \multirow[t]{2}{*}{ p'TON-6 } & 0 & $488 \pm 41$ \\
\hline & 25 & $2201 \pm 74$ \\
\hline \multirow[t]{2}{*}{ p'TON-11 } & 0 & $6.5 \pm 1.0$ \\
\hline & 25 & $95 \cdot 0 \pm 1 \cdot 2$ \\
\hline
\end{tabular}

* The data represent the mean of three determinations \pm sD.

not shown). Although additional candidate translation initiation sites (GTG) exist within the ton $B_{P . a .}$ ORF, inframe fusion of $\operatorname{ton} B_{\text {P.a. }}$. sequences upstream of a $B s r \mathrm{BI}$ restriction site (includes the ATG codon but none of the GTG codons) (Fig. 2) to lac $Z$ in the translational fusion vector pPZ30 (Fig. 1; pTON-11) yielded active enzyme (Table 2), suggesting that translation initiation begins upstream of this restriction site, likely at the indicated ATG. Expression of this translational fusion as well as a transcriptional ton $B_{\text {P.a. }}-$ lac $Z$ fusion (Fig. 1; pTON-6) was markedly enhanced under iron-limiting ( + EDDHA) conditions (Table 1). Consistent with this, a sequence exhibiting homology to the consensus Fur binding sequence (13/19 matches) was identified upstream of ton $B_{\mathrm{P} . \mathrm{a}}$, overlapping a putative $\sigma^{70}$ promoter region (Fig. 2).

The deduced TonB $\mathrm{B}_{\mathrm{P.a} . \mathrm{P}}$ polypeptide is rich in Pro $(18.4 \%)$ and exhibits a (Lys-Pro $)_{6}$ repeat typical of previously described TonB proteins. Although a substantial Glu-Pro repeat sequence, also typical of TonB proteins, was absent from the Pro-rich domain of the TonB $B_{\text {P.a. }}$ homologue, this region did exhibit some short Glu-Pro sequences (Fig. 2). A hydropathy plot of the deduced TonB sequence revealed a single region of substantial hydropathicity (L88-M108) (Fig. 2) predicted to be membrane-spanning (data not shown). This region is preceded by two basic amino acids (K83 and R85), suggestive of a leader/signal sequence, and may, in fact, represent an internal signal/ membrane anchor sequence.

\section{Isolation and characterization of a tonB mutant strain of $P$. aeruginosa}

Despite many previous successes using the gene replacement vector pSUP202 and its relatives to construct knockout mutations in various $P$. aeruginosa genes (Poole

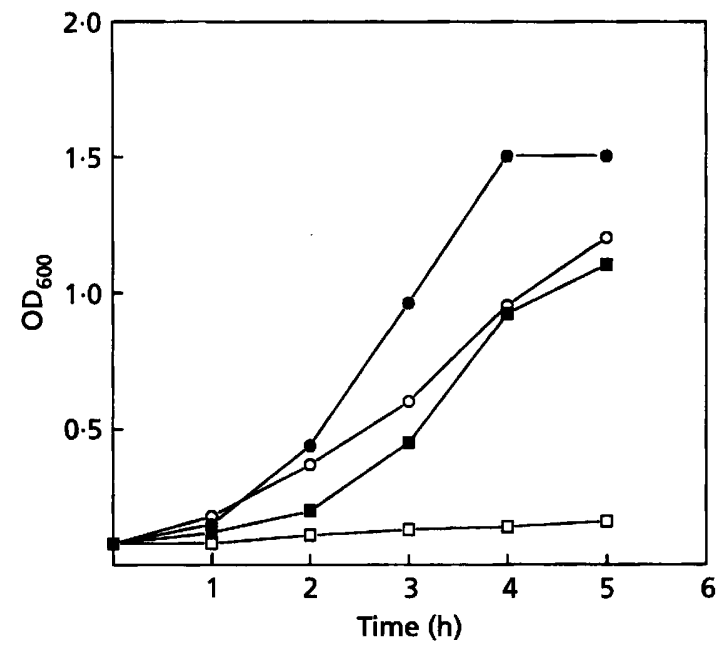

Fig. 3. Growth of $P$. aeruginosa strain PAO6609 $(O, O)$ and the ton $B$ derivative $\mathrm{K} 883(\square, \square)$ in BHI broth under iron-rich $(-E D D H A)(0, \square)$ and iron-limited (+EDDHA) (O, $\square)$ conditions.

et al., 1993a, b, c; Heinrichs \& Poole, 1993; Dean \& Poole, 1993b) all attempts at constructing a ton B mutant

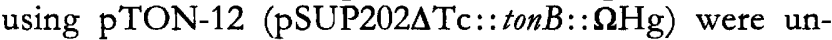
successful. Thus, the $\Omega \mathrm{Hg}$-disrupted ton $B$ gene was cloned into the newly described gene replacement vector pEX100T and ultimately inserted into the $P$. aeruginosa chromosome, replacing the wild-type copy of the gene. Successful gene replacement (as confirmed by PCR analysis of the chromosomal ton $B$ genes, data not shown) was achieved in the pyoverdine-deficient strain PAO6609 (yielding strain $\mathrm{K} 883$ ) and the pyoverdine-/pyochelindeficient strain $\mathrm{K} 372$ (yielding strain K886). tonB mutants of the pyoverdine-producing PAO1 derivative K335 were, however, not obtained, despite numerous attempts. As reported previously for ton $B$ strains of other bacteria (Bitter et al., 1993; Wang \& Newton, 1969), the tonB mutants K883 (Fig. 3) and K886 (data not shown) grew poorly in an iron-limited (+EDDHA) but not iron-rich medium while the parent strains PAO6609 (Fig. 3) and K372 (data not shown) exhibited no such growth defect in an iron-limited medium. Moreover, the growth restriction imposed on pyoverdine-deficient strains by $150 \mu \mathrm{g}$ EDDHA ml ${ }^{-1}$ in minimal medium (Poole et al., 1991), while reversed by the exogenous addition of pyoverdine or enterobactin in the case of PAO6609 and K372, was not reversed by these siderophores in the ton $B$ mutants (data not shown).

\section{Homology of Ton $B_{\text {p.a. }}$ and other TonB proteins}

Although the $\tan B_{P . a .}$ gene was cloned by its ability to complement certain features of the ton $B$ mutation in $P$. putida TE156, the predicted TonB $B_{\text {P.a. }}$ product was not very similar to the $P$. putida TonB protein $(22.3 \%$ identity). Indeed, other than the Pro-rich domain, no regions of substantial homology were identifiable in these proteins (data not shown). In contrast, TonB $B_{\text {P.a. }}$ showed 


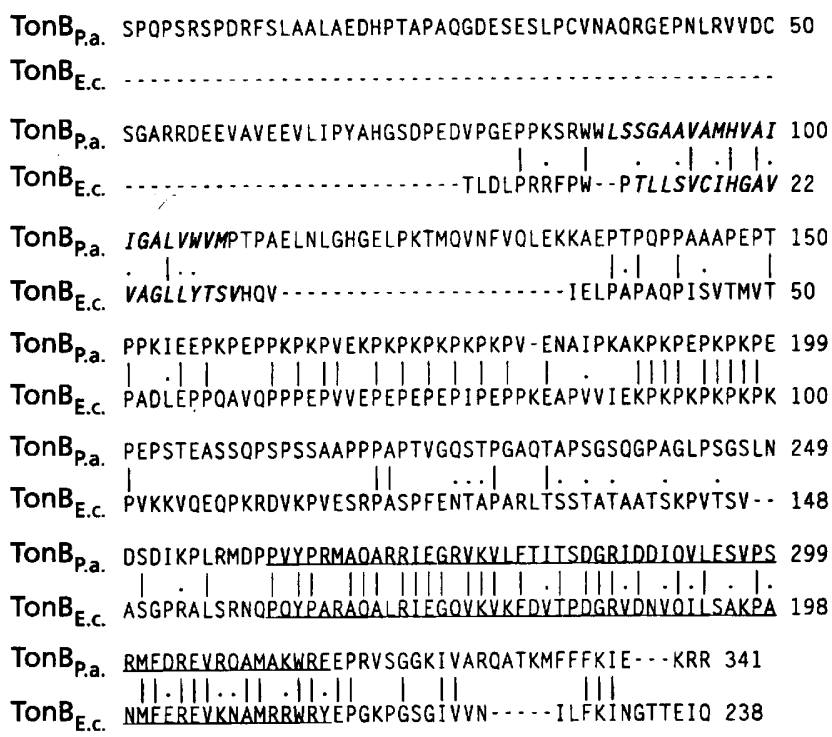

Fig. 4. Alignment of the deduced amino acid sequences of the TonB proteins of $P$. aeruginosa and $E$. coli. The alignment was carried out using the PALIGN program of the PC Gene software package (Intelligenetics). Exact matches (I) and conserved changes (.) are indicated. The cytoplasmic membraneassociated domain of TonB $\mathrm{E}_{\mathrm{E.c}}$ and a predicted transmembrane region of Ton $B_{p . a .}$ are italicized. The latter was identified using the PC Gene sOAP program. A region conserved in the TonB proteins of $P$. aeruginosa, E. coli (Postle \& Good, 1983; Postle \& Skare, 1988), Sal. typhimurium (Hannavy et al., 1990), Ent. aerogenes (Bruske \& Heller, 1993), K. pneumoniae (Bruske et al., 1993), Serr. marcescens (Gaisser \& Braun, 1991) and $Y$. enterocolitica (Koebnik et al., 1993) is underlined.

substantially more homology to TonB $\mathrm{E}_{\text {E.c. }}(33 \cdot 2 \%$ identity). In addition to the Glu-Pro/Lys-Pro domain, which is reasonably conserved between these two proteins, a region near the $C$ terminus of $\operatorname{TonB}_{\mathrm{P} . \mathrm{a} .}$ was highly similar to a region at the $\mathrm{C}$ terminus of TonB $\mathrm{E}_{\mathrm{E} . c .}$ (Fig. 4). This $\mathrm{C}$ terminal domain is also conserved in the majority of 'TonB proteins so far sequenced (Fig. 4), the exceptions being the TonB proteins of $P$. putida and $H$. influenzae. Moreover, residues Gly-174, Gly-186 and Arg-204 of TonB ${ }_{\text {E.c., }}$ shown to be important for certain activities of this protein (Traub et al., 1993), are conserved in these TonB proteins (Fig. 4). TonB $B_{\text {P.a. }}$ is substantially larger than previously described TonB proteins (341 residues in TonB $\mathrm{P}_{\text {.a. }}$ vs. 239-261 residues in the other TonB proteins).

\section{Activity of TonB $\mathrm{B}_{\text {p.a. }}$ in $E$. coli}

Given the homology between $\operatorname{TonB}_{\text {P.a. }}$ and TonB $\mathrm{B}_{\text {E.c. }}$, it was of interest to see if $\operatorname{TonB}_{\mathbf{P . a}}$. could functionally replace Ton $B_{E . c .}$ in a ton $B$ mutant strain. Thus, the cloned ton $B_{\text {P.a. }}$ gene (on plasmid pTON-4) was introduced into the tonB metE strain RK5015 and tested for its ability to restore a number of TonB-dependent functions, including utilization of ferric enterobactin and vitamin $B_{12}$, as well as sensitivity to phage $\phi 80$. The methionine requirement of RK5015 can be met by vitamin $B_{12}$. However, this requires TonB-dependent transport of vitamin $B_{12}$ into the cell. Thus, RK5015 failed to grow in minimal medium or on minimal medium plates when supplemented with vitamin $\mathrm{B}_{12}$ while its TonB $^{+}$parent strain RK5173 grew well under these conditions with a generation time in liquid medium of $0.91 \mathrm{~h}$. RK5015 carrying pTON-4 was able to grow on minimal medium containing vitamin $\mathrm{B}_{12}$, although less well than RK5173 (generation time = $2.08 \mathrm{~h}$ ), indicating that $\operatorname{TonB}_{\text {P.a. }}$ is active in E. coli. Similarly, RK5015 failed to grow on EDDHA-containing minimal medium despite enterobactin supplementation while RK5173 alone and RK5015 carrying pTON-4 demonstrated enterobactin-dependent growth in this medium, with generation times in liquid medium of 1.75 and $7.34 \mathrm{~h}$, respectively. Finally, sensitivity to phage $\phi 80$, absent in RK5015, was restored by the $\operatorname{ton} B_{\text {P.a. }}$ gene, although the plaques formed on RK5015/pTON-4 were quite hazy compared to those observed on RK5173, which were extremely clear and well-defined (data not shown). Nonetheless, the numbers of p.f.u. enumerated at any given phage dilution was essentially the same for both strains (data not shown).

\section{DISCUSSION}

The identification, in a variety of bacteria of TonB homologues (Bitter et al., 1993; Bruske \& Heller, 1993; Bruske et al., 1993; Hannavy et al., 1990; Karlsson et al., 1993b; Klesney-Tait et al., 1994; Koebnik et al., 1993; Jarosik et al., 1994) and outer-membrane proteins exhibiting homology to the family of TonB-dependent receptors (Braun et al., 1987; Cornelisson et al., 1992; Heller \& Kadner, 1985; Henderson \& Payne, 1994; Jarosik et al., 1994, 1995; Stojiljkovic \& Hantke, 1992) would seem to indicate that the TonB mechanism of energy-/receptor-dependent ligand uptake across the Gram-negative outer membrane (Postle, 1990a, 1993) is well-conserved in prokaryotes. TonB $\mathrm{P}_{\mathrm{P} . \mathrm{a}}$. displays a moderate level of homology (30\% identity, or $40 \%$ identity if the additional $\mathrm{N}$-terminal residues of Ton $\mathrm{B}_{\text {P.a. }}$ are excluded) to TonB $B_{\text {E.c. }}$ and is able to, albeit weakly, restore a number of TonB-dependent functions in an $E$. coli ton $B$ mutant. This means, presumably, that TonB $B_{P . a .}$ is able to interact, in E. coli, both with outer-membrane receptor proteins and auxiliary proteins (e.g. ExbB, ExbD) required for TonB activity and, moreover, that residues conserved between Ton $B_{P . a .}$ and Ton $B_{E . c .}$ include those important for these interactions.

While there is limited homology between the $\mathrm{N}$-terminus of $\mathrm{TonB}_{\mathrm{E} . c .}$, a region implicated in the interaction with ExbB in E. coli (Larsen et al., 1994; Karlsson et al., 1993a; Jaskula et al., 1994; Traub et al., 1993), and the corresponding region of $\operatorname{TonB}_{\mathbf{P . a}}$, this region of both proteins is characterized by the presence of a hydrophobic, predicted (in the case of Ton $B_{\text {P.a. }}$ ) membrane-spanning $\alpha$ helical domain. Furthermore, His- 20 of TonB $B_{\text {E.c. }}$ (His-19 in the mature protein is depicted in Fig. 4), which appears to be very important for TonB activity (Traub et al., 1993), is conserved in TonB $B_{P . a .}$. These may explain, in part, the activity of TonB ${ }_{\text {P.a. }}$ in $E$ coli and are probably 
important for the interaction with ExbB in E. coli and, possibly, in $P$. aeruginosa.

The Glu-160 residue of TonB $\mathrm{E}_{\text {E.c., }}$ implicated in receptor interaction (Heller et al., 1988; Bell et al., 1990) and similarly important for TonB $B_{\mathrm{E} . c .}$ activity (Traub et al., 1993; Bruske \& Heller, 1993), is not, however, conserved (at least at the same position) in $\mathrm{TonB}_{\mathrm{P} . \mathrm{a}}$. It is possible, nonetheless, that in the context of the $\mathrm{TonB}_{\mathrm{P} . \mathrm{a} . \text { protein, }}$ some other residue fulfills this role in receptor interaction. Despite the lack of an obvious Glu-160 counterpart in

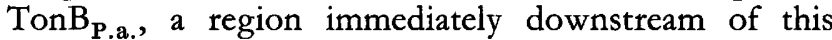
residue is highly homologous between the two proteins and fairly well-conserved amongst most TonB proteins. This domain overlaps a region capable of forming an amphipathic $\alpha$-helix which has been implicated in receptor interaction (Larsen et al., 1993). Moreover, several mutants exhibiting altered TonB activity in E. coli have been mapped to this region of TonB $B_{\text {E.c. }}$ (Traub et al., 1993). This region may, therefore, be important for the function of TonB ${ }_{P . a .}$ both in $E$. coli and in $P$. aeruginosa.

Although the apparent molecular mass of TonB $B_{\text {P.a. }}$ is substantially larger than that predicted from the $\operatorname{ton} B_{\text {P.a. }}$. sequence, anomalous migration on SDS-polyacrylamide gels is a hallmark of TonB proteins, which typically exhibit apparent molecular masses some $10 \mathrm{kDa}$ larger than that predicted from gene sequences [e.g. TonB $\mathrm{E}_{\mathrm{E} . c .}$ is predicted to be $26 \mathrm{kDa}$ based on nucleotide sequence data but migrates on polyacrylamide gels with an apparent molecular mass of $36 \mathrm{kDa}$ (Postle \& Good, 1983)]. The larger apparent molecular mass of $\mathrm{TonB}_{\mathrm{P} . \mathrm{a}}$. relative to TonB $_{\text {E.c. }}$ is, however, consistent with the sequence data which predicts it to be larger.

The alignment presented in Fig. 4 indicates that the bulk of the additional residues in TonB $B_{\text {P.a. }}$ occurs at the $\mathrm{N}$ terminus of the protein, upstream of the predicted membrane-spanning, putative internal signal/membrane anchor sequence. As such, it is likely that the extra residues are disposed to the cytoplasmic side of the cytoplasmic membrane. The functional significance of this novel $\mathrm{N}$-terminal extension is unknown and no homology between this domain and known proteins was identified during a search of the GenBank databases. It is intriguing to note, however, that an $\mathrm{N}$-terminal extension was previously identified in the ExbB homologue of $P$. putida $\left(\right.$ ExbB $_{\text {P.p. }}$ ) (Bitter et al., 1993) which was, nonetheless, active in $E$. coli. It was speculated that the presence of this $\mathrm{N}$-terminal domain in $\mathrm{ExbB}_{\mathbf{P . p} \text {. is }}$ somehow related to the nature of some TonB-dependent ferric siderophore receptors in this organism which are characterized by $\mathrm{N}$-terminal, presumed periplasmic, extensions not typical of most TonB-dependent receptors (Bitter et al., 1993). Interestingly, the outer-membrane receptor for ferric pyoverdine in $P$. aeruginosa, FpvA, a protein showing homology to the TonB-dependent family of receptors, also appears to possess a periplasmic $\mathrm{N}$ terminal extension (Poole et al., 1993c). It is possible, therefore, that the presence of this periplasmic domain in these outer-membrane receptors necessitates changes in the TonB-ExbB-ExbD complexes of these organisms which might explain the additional $\mathrm{N}$-terminal domains in ExbB $_{\text {P.p. }}$ and TonB $B_{\text {P.a. }}$.

\section{ACKNOWLEDGEMENTS}

We thank Jan Tommassen and Robert Kadner for supplying strains and Peter Weisbeek and Jean-Marie Meyer for providing pseudobactin and pyoverdine, respectively. This work was supported by a grant from the Medical Research Council of Canada. K.P. is an NSERC University Research Fellow. D. H. is the recipient of a Canadian Cystic Fibrosis Foundation studentship. C.D. is an Ontario Graduate Scholar.

\section{REFERENCES}

Ankenbauer, R. G. \& Quan, H. N. (1994). FptA, the Fe(III)pyochelin receptor of Pseudomonas aeruginosa: a phenolate siderophore receptor homologous to hydroxamate siderophore receptors. $J$ Bacteriol 176, 307-319.

Anton, M. \& Heller, K. J. (1991). Functional analysis of a Cterminally altered TonB protein of Escherichia coli. Gene 105, 23-29.

Ausubel, F. M., Brent, R., Kingston, R. E., Moore, D. D., Seidman, J. G., Smith, J. A. \& Struhl, K. (1992). Short Protocols in Molecular Biology, 2nd edn. New York: John Wiley \& Sons.

Bell, P. E., Nau, C. D., Brown, J. T., Konisky, J. \& Kadner, R. J. (1990). Genetic suppression demonstrates interaction of TonB protein with outer membrane transport proteins in Escherichia coli. $J$ Bacteriol 172, 3826-3829.

Berry, D. \& Kropinski, A. M. (1986). Effect of lipopolysaccharide mutations and temperature on plasmid transformation efficiency in Pseudomonas aeruginosa. Can J Microbiol 32, 436-438.

Bitter, W., Tommassen, J. \& Weisbeek, P. J. (1993). Identification and characterization of the exbB, exbD and tonB genes of $P_{\text {seudomonas }}$ putida WCS358: their involvement in ferric-pseudobactin transport. Mol Microbiol 7, 117-130.

Braun, V., Hantke, K., Eick-Helmerich, K., Köster, W., Pressler, U., Sauer, M., Schäffer, S., Schoffler, H., Staudenmaier, H. \& Zimmermann, L. (1987). Iron transport systems in Escherichia coli. In Iron Transport in Microbes, Plants and Animals, pp. 35-51. Edited by G. W. Winkelmann, D. van der Helm \& J. B. Neilands. Weinheim: VCH Verlagsgesellschaft.

Brewer, S., Tolley, M., Trayer, I. P., Barr, G. C., Dorman, C. J., Hannavy, K., Higgins, C. F., Evans, J. S., Levine, B. A. \& Wormald, M. R. (1990). Structure and funcion of X-pro dipeptide repeats in the TonB proteins of Salmonella typhimurium and Escherichia coli. $J$ Mol Biol 216, 883-895.

Bruske, A. K. \& Heller, K. J. (1993). Molecular characterization of the Enterobacter aerogenes ton $B$ gene: identification of a novel type of TonB box suppressor mutant. J Bacteriol 175, 6158-6168.

Bruske, A. K., Anton, M. \& Heller, K. J. (1993). Cloning and sequencing of the Klebsiella pneumoniae ton $B$ gene and characterization of Escherichia coli-Klebsiella pneumoniae TonB hybrid proteins. Gene 131, 9-16.

Cornelisson, C. N., Biswas, G. D., Tsai, J., Paruchuri, D. K., Thompson, S. A. \& Sparling, F. (1992). Gonococcal transferrinbinding protein 1 is required for transferrin utilization and is homologous to TonB-dependent outer membrane receptors. $J$ Bacteriol 174, 5788-5797.

Dean, C. R. \& Poole, K. (1993a). Cloning and characterization of the ferric enterobactin receptor gene $(p f e A)$ of Pseudomonas aeruginosa. $J$ Bacteriol 175, 317-324.

Dean, C. R. \& Poole, K. (1993b). Expression of the ferric 
enterobactin receptor $(\mathrm{PfeA})$ of $P$ seudomonas aeruginosa : involvement of a two-component regulatory system. Mol Microbiol 8, 1095-1103.

Eick-Helmerich, K. \& Braun, V. (1989). Import of biopolymers into Escherichia coli: nucleotide sequences of the $e \times b B$ and $e \times b D$ genes are homologous to those of the tolQ and tolR genes. J Bacteriol 171, 5117-5126.

Evans, J. S., Levine, B. A., Trayer, I. P., Dorman, C. J. \& Higgins, C. F. (1986). Sequence imposed structural constraints in the TonB protein of Escherichia coli. FEBS Lett 208, 211-216.

Fellay, R., Frey, J. \& Krisch, H. (1987). Interposon mutagenesis of soil and water bacteria: a family of DNA fragments designed for in vitro insertional mutagenesis of Gram-negative bacteria. Gene 52, 147-154.

Figurski, D. H. \& Helinski, E. R. (1979). Replication of an origincontaining derivative of plasmid RK2 dependent on a plasmid function provided in trans. Proc Natl Acad Sci US A 76, 1648-1652.

Fischer, E., Gunter, K. \& Braun, V. (1989). Involvement of ExbB and TonB in transport across the outer membrane of Escherichia coli: phenotypic complementation of exbB mutants by overexpressed ton $B$ and physical stabilization of TonB by ExbB. $J$ Bacteriol 171, 5127-5134

Gaisser, S. \& Braun, V. (1991). The tonB gene of Serratia marcescens: sequence, activity and partial complementation of Escherichia coli tonB mutants. Mol Microbiol 5, 2777-2787.

Guterman, S. K. \& Dann, L. (1973). Excretion of enterochelin by $e x b A$ and $e x b B$ mutants of Escherichia coli.J Bacteriol 114, 1225-1230.

Günter, K. \& Braun, V. (1990). In vivo evidence for FhuA outer membrane receptor interaction with the Ton $B$ inner membrane protein of Eschericbia coli. FEBS Lett 274, 85-88.

Hannavy, K., Barr, G. C., Dorman, C. J., Adamson, J., Mazengera, L. R., Gallagher, M. P., Evans, J. S., Levine, B. A., Trayer, I. P. \& Higgins, C. F. (1990). TonB protein of Salmonella typhimurium: a model for signal transduction between membranes. J Mol Biol 216, 897-910.

Hantke, K. \& Zimmermann, L. (1981). The importance of the exbB gene for vitamin $\mathrm{B}_{12}$ and ferric iron transport. FEMS Microbiol Lett 12, 31-35.

Heinrichs, D. E. \& Poole, K. (1993). Cloning and sequence analysis of a gene ( $p c b \mathrm{R})$ encoding an AraC family activator of pyochelin and ferripyochelin receptor synthesis in Pseudomonas aeruginosa. I Bacteriol 175, 5882-5889.

Heinrichs, D. E., Young, L. \& Poole, K. (1991). Pyochelin-mediated iron transport in Pseudomonas aeruginosa: involvement of a highmolecular-mass outer membrane protein. Infect Immun 59, 3680-3684.

Heller, K. \& Kadner, R. J. (1985). Nucleotide sequence of the gene for the vitamin $B_{12}$ receptor in the outer membrane of Eschericbia coli. J Bacteriol 161, 904-908.

Heller, K. J., Kadner, R. J. \& Gunther, K. (1988). Suppression of the btuB451 mutation by mutations in the ton $B$ gene suggests a direct interaction between TonB and TonB-dependent receptor proteins in the outer membrane of Escherichia coli. Gene 64, 147-153.

Henderson, D. P. \& Payne, S. M. (1994). Characterization of the Vibrio cholerae outer membrane heme transport protein HutA: sequence of the gene, regulation of expression, and homology to the family of TonB-dependent proteins. J Bacteriol 176, 3269-3277. Hohnadel, D., Haas, D. \& Meyer, J.-M. (1986). Mapping of mutations affecting pyoverdine production in Pseudomonas aeruginosa. FEMS Microbiol Lett 36, 195-199.

Jarosik, G. P., Sanders, J. D., Cope, L. D., Meller-Eberhard, U. \& Hansen, E. J. (1994). A functional tonB gene is required for both utilization of heme and virulence expression by Haemophilus influenzae type b. Infect Immun 62, 2470-2477.

Jarosik, G. P., Maciver, I. \& Hansen, E. J. (1995). Utilization of transferrin-bound iron by Haemophilus influenzae requires an intact tonB gene. Infect Immun 63, 710-713.

Jaskula, J. C., Letain, T. E., Roof, S. K., Skare, J. T. \& Postle, K. (1994). Role of the Ton $B$ amino terminus in energy transduction between membranes. $J$ Bacteriol 176, 2326-2338.

Kampfenkel, K. \& Braun, V. (1992). Membrane topology of the Eschericbia coli ExbD protein. J Bacteriol 174, 5485-5487.

Kampfenkel, K. \& Braun, V. (1993). Topology of the ExbB protein in the cytoplasmic membrane of Escherichia coli. J Biol Chem 268, 6050-6057.

Karlsson, M., Hannavy, K. \& Higgins, C. F. (1993a). A sequencespecific function for the $\mathrm{N}$-terminal signal-like sequence of the TonB protein. Mol Microbiol 8, 379-388.

Karlsson, M., Hannavy, K. \& Higgins, C. F. (1993b). ExbB acts as a chaperone-like protein to stabilize TonB in the cytoplasm. Mol Microbiol 8, 389-396.

Keen, N. T., Tamaki, S., Kobayashi, D. \& Trollinger, D. (1988). Improved broad-host-range plasmids for DNA cloning in Gramnegative bacteria. Gene 70, 191-197.

Killmann, H., Benz, R. \& Braun, V. (1993). Conversion of the FhuA transport protein into a diffusion channel through the outer membrane of Escherichia coli. EMBO J 12, 3007-3016.

Klesney-Tait, A., Jarosik, G. P., Radolf, J. D. \& Hansen, E. J. (1994). Cloning of the tonB gene from Haemophilus ducreyi, abstr. D-171. In Abstracts of the 94th General Meeting of the American Society for Microbiology 1994, p. 126. Washington, DC: American Society for Microbiology.

Koebnik, R., Băumler, A. J., Heesemann, J., Braun, V. \& Hantke, K. (1993). The TonB protein of Yersinia enterocolitica and its interactions with TonB-box proteins. Mol Gen Genet 237, 152-160.

Larsen, R. A., Wood, G. E. \& Postle, K. (1993). The conserved proline-rich motif is not essential for energy transduction by Escherichia coli TonB protein. Mol Microbiol 10, 943-953.

Larsen, R. A., Thomas, M. G., Wood, G. E. \& Postle, K. (1994). Partial suppression of an Escherichia coli TonB transmembrane mutation (V17) by a missense mutation in ExbB. Mol Microbiol 13, $627-640$.

Lundrigan, M. D. \& Kadner, R. J. (1986). Nucleotide sequence of the ferrienterochelin receptor FepA in Escberichia coli: homology among outer membrane receptors that interact with TonB. J Biol Chem 261, 10797-10801.

Marmur, J. (1961). A procedure for the isolation of deoxyribonucleic acid from microorganisms. $J$ Mol Biol 3, 208-218.

Miller, J. H. (1992). A Short Course in Bacterial Genetics. Cold Spring Harbor, NY: Cold Spring Harbor Laboratory.

Neidhardt, F. C. (1987). Escherichia coli and Salmonella typhimurium: Cellular and Molecular Biology. Washington, DC: American Society for Microbiology.

Poole, K., Schiebel, E. \& Braun, V. (1988). Molecular characterization of the hemolysin determinant of Serratia marcescens. $J$ Bacteriol 170, 3177-3188.

Poole, K., Young, L. \& Neshat, S. (1990). Enterobactin-mediated iron transport in Pseudomonas aeruginosa. J Bacteriol 172, 6991-6996.

Poole, K., Neshat, S. \& Heinrichs, D. (1991). Pyoverdine-mediated iron transport in Pseudomonas aeruginosa: involvement of a highmolecular-mass outer membrane protein. FEMS Microbiol Lett 78, 1-5.

Poole, K., Heinrichs, D. E. \& Neshat, S. (1993a). Cloning and 
sequence analysis of an EnvCD homologue in Pseudomonas aeruginosa: regulation by iron and possible involvement in the secretion of the siderophore pyoverdine. Mol Microbiol 10, 529-544.

Poole, K., Krebes, K., McNally, C. \& Neshat, S. (1993b). Multiple antibiotic resistance in Pseudomonas aeruginosa: evidence for involvement of an efflux operon. J Bacteriol 175, 7363-7372.

Poole, K., Neshat, S., Krebes, K. \& Heinrichs, D. E. (1993c). Cloning and nucleotide sequence analysis of the ferripyoverdine receptor gene $f p v A$ of Pseudomonas aeruginosa. J Bacteriol 175, 4597-4604.

Postle, K. (1990a). TonB and the Gram-negative dilemma. Mol Microbiol 4, 2019-2025.

Postle, K. (1990b). Aerobic regulation of the Eschericbia coli tonB gene by changes in iron availability and the fur locus.J Bacteriol 172, 2287-2293.

Postle, K. (1993). TonB protein and energy transduction between membranes. J Bioenerget Biomembr 25, 591-602.

Postle, K. \& Good, R. F. (1983). DNA sequence of the Eschericbia coli tonB gene. Proc Natl Acad Sci US A 80, 5235-5239.

Postle, K. \& Skare, J. T. (1988). Escherichia coli TonB protein is exported from the cytoplasm without proteolytic cleavage of its amino terminus. J Biol Chem 263, 11000-11007.

Roof, S. K., Allard, J. D., Bertrand, K. P. \& Postle, K. (1991). Analysis of Escherichia coli TonB topology by use of PhoA fusions. $J$ Bacteriol 173, 5554-5557.

Rutz, J. M., Liu, J., Lyons, J. A., Goranson, J., Armstrong, S. K., Mclntosh, M., Feix, J. B. \& Klebba, P. E. (1992). Formation of a gated channel by a ligand-specific transport protein in the bacterial outer membrane. Science 258, 471-475.

Sambrook, J., Fritsch, E. F. \& Maniatis, T. (1989). Molecular Cloning: a Laboratory Manual. Cold Spring Harbor, NY: Cold Spring Harbor Laboratory.

Schoffler, H. \& Braun, V. (1989). Transport across the outer membrane of Escherichia coli $\mathrm{K} 12$ via the FhuA receptor is regulated by the TonB protein of the cytoplasmic membrane. Mol Gen Genet 217, 378-383.

Schramm, E., Mende, J., Braun, V. \& Kamp, R. M. (1987). Nucleotide sequence of the colicin B activity gene $c b a$ : consensus pentapeptide among TonB-dependent colicins and receptors. $J$ Bacteriol 169, 3350-3357.
Schweizer, H. P. (1991a). Eschericbia-Pseudomonas shuttle vectors derived from pUC18/19. Gene 97, 109-112.

Schweizer, H. P. (1991b). Improved broad-host-range lac-based plasmid vectors for the isolation and characterization of protein fusions in Pseudomonas aeruginosa. Gene 103, 87-92.

Schweizer, H. P. \& Hoang, T. T. (1995). An improved system for gene replacement and $x y l E$ fusion analysis in Pseudomonas aeruginosa. Gene 158, 15-22.

Simon, R., Priefer, U. \& Puehler, A. (1983). A broad host range mobilization system for in vivo genetic engineering: transposon mutagenesis in Gram-negative bacteria. Bio/Technology 1, 784-791.

Skare, J. T. \& Postle, K. (1991). Evidence for a TonB-dependent energy transduction complex in Eschericbia coli. Mol Microbiol 5, $2883-2890$

Skare, J. T., Ahmer, B. M. M., Seachord, C. L., Darveau, R. P. \& Postle, K. (1993). Energy transduction between membranes. TonB, a cytoplasmic membrane protein, can be chemically cross-linked in vivo to the outer membrane receptor FepA. J Biol Chem 268, 16302-16308.

Spaink, H. P., Okker, R. J. H., Wijffelman, C. A., Pees, E. \& Lugtenberg, B. J. J. (1987). Promoters in the nodulation region of the Rbizobium leguminosarum Sym plasmid pRL1J1. Plant Mol Biol9, 27-39.

Staskawicz, B., Dahlbeck, D., Keen, N. \& Napoli, C. (1987). Molecular characterization of cloned avirulence genes from race 0 and race 1 of Pseudomonas syringae pv. glycinea. J Bacteriol 169, 5789-5794.

Stojiljkovic, I. \& Hantke, K. (1992). Hemin uptake system of Yersinia enterocolitica: similarities with other TonB-dependent systems in Gram-negative bacteria. EMBO J 11, 4359-4367.

Tabor, S. \& Richardson, C. C. (1985). A bacteriophage T7 RNA polymerase/promoter system for controlled exclusive expression of specific genes. Proc Natl Acad Sci USA 82, 1074-1078.

Traub, l., Gaisser, S. \& Braun, V. (1993). Activity domains of the TonB protein. Mol Microbiol 8, 409-423.

Wang, C. C. \& Newton, A. (1969). Iron transport in Escberichia coli: relationship between chromium sensitivity and high iron requirement in mutants of Eschericbia coli. J Bacteriol 98, 1135-1141.

Received 12 January 1996; accepted 22 January 1996. 